\title{
Opportunity Cost Classification of Goods and Markets ${ }^{1}$
}

\author{
Davor Mance \\ Faculty of Economics, University of Rijeka, Croatia \\ davor.mance@efri.hr \\ Nenad Vretenar \\ Faculty of Economics, University of Rijeka, Croatia \\ vretenar@efri.hr \\ Jana Katunar \\ Faculty of Economics, University of Rijeka, Croatia \\ jana@efri.hr
}

\section{ABSTRACT}

Sixty years ago, Samuelson's "Pure Theory of Public Expenditure" expounded the classification of goods, and Bain's "Economies of Scale, Concentration and the Condition of Entry in Twenty Manufacturing Industries" expounded the structure-conduct-performance paradigm. To the present day, rivalry in- and excludability from consumption classify goods, and subadditivity and irreversibility in production classify market structure. Opportunity costs of production in the form of prospective sunk costs incentivise investment and production, and the sunk costs themselves induce subadditivities, specialization and convexity of the marginal rate of technical substitution. Opportunity costs in consumption are determined by the marginal costs of replacement. In light of the recent Nobel price award to Jean Tirole, we revisit some of the forgotten discussions and clarify some of the terminology under a more economic framework of opportunity costs.

Keywords: classification of goods and markets, opportunity costs, prospective sunk costs

JEL: D47, D52, H41

\section{Introduction}

Sixty years ago, Samuelson's (1954) formalisation of Musgrave's (1939) theory gave a seminal distinction between public consumption goods and private consumption goods that never set a universal rule for public expenditures,

1 This work has been supported by the University of Rijeka under the project numbers 13.02.1.3.11 and 13.02.1.2.09.

Mance, D., Vretenar, N., \& Katunar, J. (2015). Opportunity Cost Classification of 119 Goods and Markets. International Public Administration Review, 13(1), 119-134. 
as initially intended. Table 1 shows the Samuelson's (1954) subtractability in consumption criterion also known as rivalry in consumption, depletability, scarcity, or summarily: opportunity cost in consumption (Buchanan, 2008).

Table 1: The classification of goods according to the consumption subtraction criterion

\begin{tabular}{|c|c|}
\hline $\begin{array}{c}\text { The consumption of a good by one } \\
\text { consumer leads to a subtraction of } \\
\text { consumption of some other consumer }\end{array}$ & $\begin{array}{c}\text { The consumption of a good by one } \\
\text { consumer leads to no subtraction of } \\
\text { consumption of any other consumer }\end{array}$ \\
\hline Private consumption goods & Collective consumption goods \\
\hline
\end{tabular}

Source: Samuelson (1954).

Musgrave (1959) added a second dimension: excludability. The importance of excludability and property rights was stressed by Coase (1960), Olson (1965), and Ostrom (2003) as the criteria merged into the standard textbook combination shown in table 2.

Table 2: Rivalry and excludability criteria

\begin{tabular}{|c|c|c|c|}
\hline & \multicolumn{2}{|c|}{ Excludability from consumption } \\
\hline & & Excludable & Non Excludable \\
\hline \multirow{2}{*}{$\begin{array}{l}\text { Subtractability } \\
\text { from consumption }\end{array}$} & Subtractable & Pure private goods & Common goods \\
\hline & Non subtractable & Club goods & Pure public goods \\
\hline
\end{tabular}

Buchanan $(1965,2008)$ analysed club goods, and Ostrom $(1977,1996,2003)$ common goods and common pool resources. The excludability criterion is of institutional (legal and political) and technical (feasibility and efficiency) nature, so there is no unique and consistent economic representation. Samuelson's goal of finding an overarching classification of goods that would legitimise governmental provision of public goods has not been achieved. So, the classification neither explains nor legitimises governmental role in the provision of goods: governments mostly provide private consumption goods, and collective consumption goods are mostly provided by the private market as they are more efficiently produced in a competitive market based system (Wisniewski, 2013). Even in the field of market structures, empirical research does not conform to the theory and market concentration allows no deduction about competitiveness (Demsetz, 1968). Following the groundwork by Bain (1954) and Demsetz (1968), Baumol's et al. (1982) Theory of contestable markets and endogenous cost structures entered the textbooks as shown in table 3.

This approach to goods and market structure classification uses exclusively economic terms, and as we shall see, is fully commensurable with the previous classification of goods. 
Table 3: Market classification according to irreversibility and jointness in production

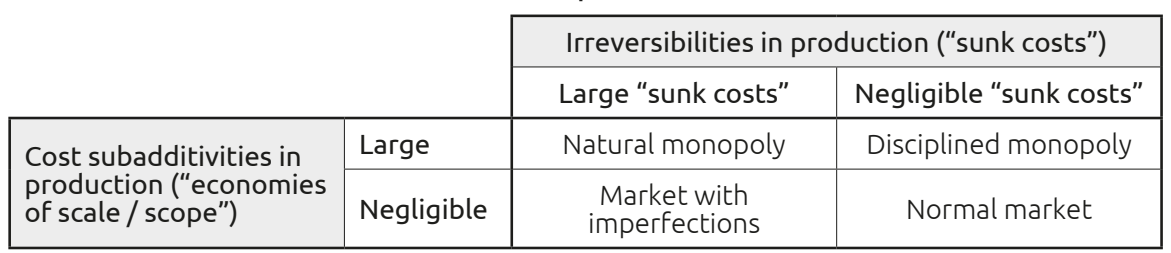

Source: Baumol et al. 1982.

\section{Interdependence of Economics and Institutions}

Formally, institutions are laws, rules, regulations, and other formal or informal social norms of behaviour (the substantive definition). Functionally, institutions create and structure incentives for desirable behaviour (North, 1990). The rivalry and excludability criteria actually show the interdependence of economic realities about the scarcity of a resource and institutional possibilities of mitigating that scarcity by allowing for an allocation mechanism. The role of the economic institutional mechanism design is to provide for the most suitable allocation mechanism (Hurwicz, 1960, 1973; Hurwicz \& Reiter, 2006) being the one mechanism with the highest informational efficiency (Hayek, 1945) communicating the dispersed information about desires and resourcefulness of individuals in society. Institutional mechanisms give incentives for the production of goods, their allocation, and for the market structures to form just as Bain (1954) has supposed. Economic reality, i.e. scarcity determines market structure. Market structure determines the gametheoretical conduct of players, and this determines their performance. An endogenously deductive process of causation is explained in detail as follows.

The connection between goods and markets is normally unclear, as the classification belongs to different subjects: public finance and industrial organisation as shown in table 4.

Table 4: Institutional and economic classification criteria

\begin{tabular}{|l|l|c|c|}
\cline { 3 - 4 } \multicolumn{2}{c|}{} & \multicolumn{2}{|}{$\begin{array}{r}\text { Property rights existence and market pricing } \\
\text { possibility }\end{array}$} \\
\cline { 2 - 4 } \multicolumn{2}{l|}{} & Positive price, $P_{x}>\mathbf{0}$ & Zero price, $P_{x}=\mathbf{0}$ \\
\hline $\begin{array}{l}\text { Subtractability, rivalry, } \\
\text { and depletability in } \\
\begin{array}{l}\text { consumption: marginal } \\
\text { costs of replacement. }\end{array}\end{array}$ & $M C_{x}>\mathbf{0}$ & $\begin{array}{c}\text { Pure private goods } \\
M C_{x}>0, P_{x}>0\end{array}$ & $\begin{array}{c}\text { Common goods } \\
M C_{x}>0, P_{x}=0\end{array}$ \\
\cline { 2 - 4 } & $M C_{x}=0$ & $\begin{array}{c}\text { Club goods } \\
M C_{x}=0, P_{x}>0\end{array}$ & $\begin{array}{c}\text { Pure public goods } \\
M C_{x}=P_{x}=0\end{array}$ \\
\hline
\end{tabular}

Source: Author's own representation.

The horizontal axis, the excludability criterion is a component of property rights. Property rights are themselves institutional public goods, as a welldefined, enforceable, transferable and exclusive property rights system is a necessary state of the world for an effective market allocation to take place 
(Demsetz, 1967,2008, 2011). There are two basic types of organisation systems for the purpose of allocation decision-making: centralised systems based on top-down allocation rules (lotteries, majoritarian voting systems, commonlaw evolutionary rules, committees, and dictatorships), and a decentralised market allocation system based on voluntary trade and cooperation including homesteading for piously non owned resources. Centralised allocation rules cannot achieve maximisation of welfare as allocation is imposed on individuals (Sen, 1977, p. 53), although there are many occasions where such decision-making rules are necessary, for example in case of disputes. But even a centralised economy needs property rights. The Tirole's (2006) socialist enterprise model needs a capitalist manager with sunk-cost collateral to mitigate moral-hazard.

The Robbinsian (1932) "What? How? For whom?" is impossible without property rights even in the case of centrally planned economies, as property rights confer necessary information and incentives. Primarily, property rights make allocation by prices according to the principle of scarcity possible. A full set of well-defined, enforceable, transferable, and exclusive property rights is indispensable for the decentralised market allocation of goods. Unpriced goods without property rights or other forms of exclusion are available free of charge $\left(P_{x}=0\right)$, and anybody can free ride on them. Users rush to convert the free resources into possession and ownership: a race that Hardin (1968) described as tragedy of the commons. As Ostrom (2003) has shown, the tragedy of the commons does not need to occur if users of the common resource are able to design and institutionalize a mechanism of control. Efficient and sustainable production needs a set of rules and incentives. For Demsetz $(1967,2011)$, property rights primarily guide incentives for greater internalisation of externalities. An externality is a property of competitive social relationships that remains external to the market economy because of its high cost of internalisation. For Demsetz $(1967,2011)$ therefore, externalities are economically efficient. The same holds for information asymmetries that are too costly to internalise. Any production may also be seen as a combination of institutionally permissible or unconstrained human action. What shall be constrained, is a question of ethics and what is efficient to constrain, is decided by transaction costs and technical feasibility. Unethical behaviour with lower costs than internalisation policies is efficient, and property rights drive transaction costs down to the point of efficient internalisation.

Accumulation of capital (in any form) is the single most important determinant of economic development. One particular aspect of capital is of particular interest: the sunk investment. An investment is sunk if it is specialized to the point that it has no substitution alternative, thus having no opportunity cost of production, and an endless value of risk or uncertainty in case of failure. Before being sunk, the potential investment has an opportunity cost of capital equal to the value of the real option of the investment and the level 
of risk or uncertainty equal to the prospective sunk cost. Sunk costs thus create specialization, cost irreversibilities and cost subadditivities that are major barriers to entry according to Baumol et al. (1982) but also increase the risks as specialization comes at the price of decreasing substitutability of productive resources and decreasing opportunity costs of production. So, without effective property rights, there is no incentive for risk-taking, investment, specialization, and efficient production with cost subadditivities. Prospective sunk investments increase opportunity costs of production and real option values. Opportunity cost of production is a two sided coin: on one side there is a possibility of market protection of incumbents against potential entrants and on the other side, there is possibility of higher risk as investment is sunk. Present anti-trust policies seem to be concerned only with the former problem of market centralisation, and less with the latter problem of entrepreneurship and risk. So, the anti-trust policies have to weigh between following rules: the less supplementary the resources (the lower the opportunity costs of production), the more convex the production possibility frontier (to the origin), and higher the cost subadditivities, i.e. higher the economies of scale and scope, and higher the efficiency in production, but also, higher the sunk costs, i.e. the risks for the investor.

Thus, the characteristics of resources, production functions and goods, endogenously define the characteristics of markets that furthermore influence strategy and performance, as in a standard Harvard "StructureConduct-Performance" model (Bain, 1954), and "Contestable Markets" theory (Baumol, 1982; Baumol et al., 1982). The opportunity costs of production reflect risk and reward possibilities. Types of goods do ultimately determine types of markets and there are two types of goods producing inefficient results: club goods and common goods.

\section{Opportunity Cost Based Classification of Goods}

Alternative ends, tastes and preferences are subjective and exogenous to theoretical economic analysis. They are the opportunity costs of consumption. Opportunity cost is an important concept in economics as it expresses the basic relationship between scarcity and choice (Buchanan, 2008). Scarcity according to Cairncross (1944) and Samuelson (1954) has an exclusively social, demand oriented context in the sense of rivalry, or competition for resources. Demsetz's (1964, p. 20) perspective on scarcity is the production side: the marginal cost of replacement. Table 5 shows the same four types of goods, this time presented according to their opportunity costs of production and opportunity costs in consumption. 
Table 5: Interdependence of economics and institutions

\begin{tabular}{|l|l|c|c|}
\cline { 3 - 4 } \multicolumn{2}{c|}{} & \multicolumn{2}{c|}{ The institutional framework } \\
\cline { 3 - 4 } \multicolumn{1}{c|}{$\begin{array}{l}\text { Economic } \\
\text { facts }\end{array}$} & $\begin{array}{c}\text { Resource or } \\
\text { good is scarce }\end{array}$ & $\begin{array}{c}\text { Positive opportunity } \\
\text { costs of production and } \\
\text { positive opportunity costs } \\
\text { in consumption. }\end{array}$ & $\begin{array}{c}\text { No opportunity costs of } \\
\text { production and positive } \\
\text { opportunity costs in } \\
\text { consumption. }\end{array}$ \\
\cline { 2 - 4 } & $\begin{array}{c}\text { Resource or } \\
\text { good is not } \\
\text { scarce }\end{array}$ & $\begin{array}{c}\text { Positive opportunity } \\
\text { costs of production and } \\
\text { no opportunity costs in } \\
\text { consumption. }\end{array}$ & $\begin{array}{c}\text { No opportunity costs } \\
\text { of production and no } \\
\text { opportunity costs in } \\
\text { consumption. }\end{array}$ \\
\hline
\end{tabular}

Source: Author's own representation.

The opportunity cost of production is the basic economic incentive of production and important decision-making factor in the allocation of resources. It incorporates risks and rewards of sunk costs in a single measure: the investment real option. It is the part of an investment that is irreversible, the highest possible amount to be lost, and simultaneously a barrier to entry for competitors, once the investment option is exercised, guaranteeing monopoly rents.

The opportunity cost in consumption determines the allocative efficiency of existing goods and gives the optimal pricing to clear the market. Club goods and common goods therefore show some allocation problems. Club goods are made artificially scarce by the institutions of the society. Common goods lack necessary institutions for efficient allocation. Samuelson's (1954) collective consumption goods have zero marginal costs $\left(M C_{x}\right)$ of consumption for any good $x_{n}$ subscript $n$ denoting possible consumption quantities $Q_{n}$ $(n=1,2,3, \ldots, N)$ for all potential consumption quantities across the entire production / consumption spectrum:

$$
\forall x_{n} \in X ; \quad M C\left(\sum_{n=1}^{N} x_{n}\right)=0 ; \quad n \in \mathbb{N}
$$

The replacement cost function is boundless with respect to demanded quantity $n$ :

$$
\forall x_{n} \in X ; \quad T C\left(x_{1}\right)=T C\left(x_{1+n}\right) ; \quad\left|x_{n}\right| \rightarrow \infty ; \quad n \in \mathbb{N}
$$

The production/consumption schedule is independent of the total production/ consumption quantity. In case of Samuelson's (1954) collective consumption goods, the production function consists entirely of sunk costs: a constant. In this case, the cost function is extremely subadditive. The marginal cost of the production/consumption schedule does not decrease monotonically with the quantity: the costs are nil from the very first production unit.

The marginal production/consumption costs, for private consumption goods are instead positive: 


$$
\forall x_{n} \in X ; \quad M C\left(\sum_{n=1}^{N} x_{n}\right)>0 ; \quad n \in \mathbb{N}
$$

It implies that the production/consumption function is bounded in respect to some final quantity of produced goods $\mathrm{M}$ :

$$
\forall x_{n} \in X ; \quad T C\left(x_{1}\right)<T C\left(x_{1+n}\right) ; \quad\left|x_{n}\right| \leq M ; \quad n \in \mathbb{N}, M \in \mathbb{N}
$$

As Baumol (1972) pointed out, the production possibility frontier when using a positive externality (or emitting a negative externality) may present a non-convex shape. The allocative efficiency depends on the cross-section of opportunity costs in consumption and prices, and is satisfied when $P_{x}=C_{x}$. So, for private consumption goods $P_{x}=M C_{x}>0$, and for collective consumption goods $P_{x}=M C_{x}=0$. Table 6 depicts the previous statements more clearly.

Table 6: Opportunity costs in consumption and opportunity cost of production

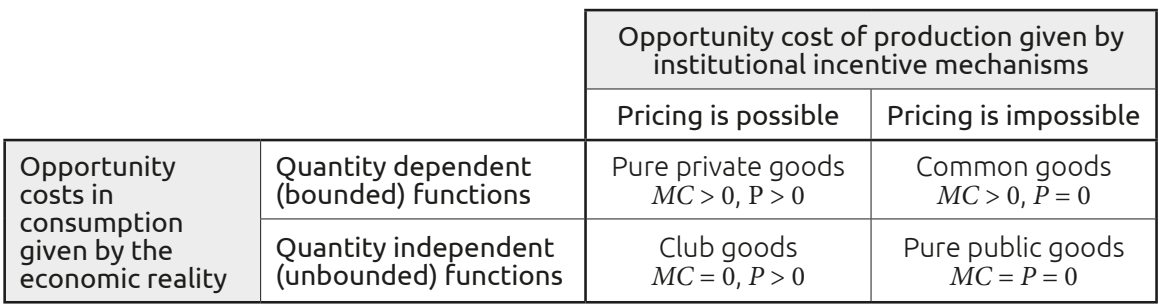

Source: Author's own representation.

Sunk costs induce economies of scale, i.e. subadditive production cost functions (Weitzman, 1983). Zero marginal costs in consumption imply superadditive consumption functions: no subtraction from further consumption, i.e. no opportunity costs in consumption. It is the goal of the economic optimization problem to produce at least cost. Goods with no rivalry in consumption and without any costs of replacement are produced with zero marginal costs, i.e. without opportunity costs in consumption. Which is very often equalised with monopoly power (does anybody still remember the Microsoft lawsuit case?). To say that a firm is guilty of monopoly power because its average cost curve is falling is to say that it is guilty of being efficient. A successful market structure depends not so much on allocative (static) as on productive (dynamic) efficiency. In an allocatively efficient industry, companies equalise marginal cost and price. Companies with large sunk investments and no marginal costs of replacement cannot possibly charge zero price.

It is not the physical states of the world which one cannot influence that one shall be guilty of, but only his actions and coercions and/or abuses of power to coerce. 
There are some goods that are usually wrongly classified: cinemas and air flights are fine examples. They are wrongly put into the category of nonrival goods, as, there is no opportunity cost of usage for the next customer as long as there are empty seats. This view disregards the non-monotonicity and boundaries of production functions. These instead are lumpy goods, meaning their production function is not monotone, and they are ultimately subtractable at the end of every supply unit that consists of many consumption units, subtractable in lumps. Normally, these goods are also composite of two or more other goods. For example cinemas. No two seats in a cinema are equal, and ultimately a composite service is sold: the movie projection, which is non rivalrous up to the last seat, but a single seat in the projection room is rivalrous (and with positive marginal costs in consumption). When at least one part of the composite service is subtractable, the entire composite service is subtractable, because adding a superadditive consumption function to a nonsuperadditive consumption function yields a non-superadditive consumption function, i.e. a private consumption good. So, where is the big problem within the classification of goods? Let us think of an example. Angelina Jolie may make a movie only once, which is a sunk cost, but the movie may be viewed an unlimited number of times, in a quantitatively unbounded consumption function. So, the problem is the production scarcity of Angelina Jolie movies. But once they are produced, they are not rival or subtractable in consumption. Angelina Jolie is a natural monopolistic provider of Angelina Jolie movies. The question her fans are interested in is not how to punish her for the monopoly position, but how to incentivize her to produce more movies. This is also the main point of Demsetz $(1964,1966,1967,1968,2008,2011)$, that has been missed by the market regulators in the past.

The most common definition of monopoly translates into a market structure with just one supplier. This is a neo-classic substantive definition. A functional definition is concentrated on monopoly power: a market structure with the producer having market power to control either prices or quantities. According to Baumol (1982) a monopoly is an uncontestable market position. It is a functional definition that includes not only what is seen, but tries also to include what is not seen: the possibility to contest the market power of the incumbent producer. So, even if the monopolist has market power to control prices or quantities, he won't abuse his power if his position can be contested by a sudden entrant, which could be detrimental for his profits.

\section{Opportunity Cost Based Classification of Markets}

Table 3 (Market classification according to the irreversibility and jointness in production criteria) has according to Weitzman (1983) a serious flaw. Weitzman postulated that in a timeless production function and without sunk costs no fixed costs are possible and subsequently no cost subadditivities may exist. Table 7 shows the implications of the critique. 
Table 7: Market structure according to jointness and irreversibility in production

\begin{tabular}{|c|c|c|c|}
\hline & & \multicolumn{2}{|c|}{$\begin{array}{l}\text { Irreversibility in production } \\
\text { ("sunk costs") }\end{array}$} \\
\hline & & $\begin{array}{l}\text { Large } \\
\text { "sunk costs" }\end{array}$ & $\begin{array}{l}\text { Neglectable } \\
\text { "sunk costs" }\end{array}$ \\
\hline \multirow{2}{*}{$\begin{array}{l}\text { Jointness in } \\
\text { production } \\
\text { ("Economies of scale } \\
\text { / scope") }\end{array}$} & $\begin{array}{l}\text { Large } \\
F C>0, A C^{\prime}<0, M C<A C\end{array}$ & Natural monopoly & IMPOSSIBLE! \\
\hline & $\begin{array}{l}\text { Negligible } \\
F C=0, A C^{\prime} \geq 0, M C \approx A C\end{array}$ & IMPOSSIBLE! & Normal market \\
\hline
\end{tabular}

Source: Authors' own representation.

The Weitzman (1983) critique implies two impossible results shown in the table 7. The subadditivity in production implies sinking average costs and positive sunk costs. According to this view, only two opposite market structures are possible: normal market and natural monopoly. Natural monopoly is a direct consequence of the sunk cost. But the sunk cost is a double sided coin: it is simultaneously a source of opportunity and a source of risk. This has significant implications for the anti-trust policies as they take into account only the opportunities but not the risks. Table 8 draws on that conclusion and shows a modified representation with prospective sunk costs as a maximum value at risk for an investment and representing the opportunity costs of production, and the marginal cost of replacement representing the opportunity cost in consumption.

Table 8: Opportunity costs of production and opportunity costs in consumption

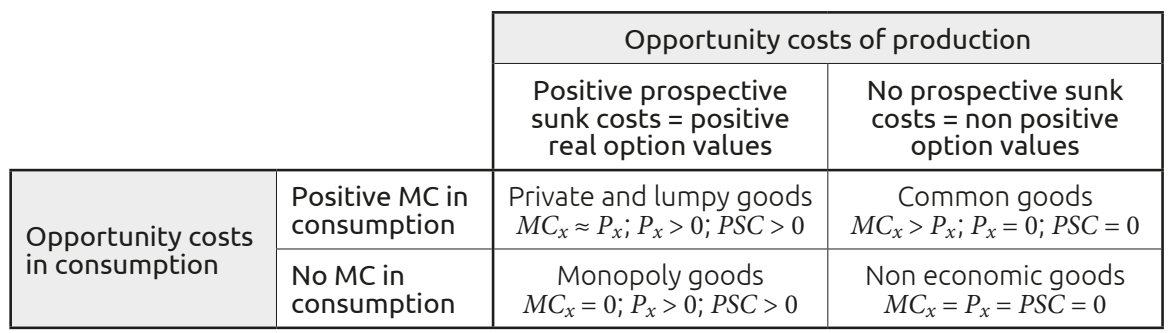

Source: Authors' own representation.

Any categorisation of goods has to start from the basic economic question of scarcity, i.e. the opportunity costs in consumption and the effects of institutions on allocating the consumption of these scarce resources. Any consumption of products that are not readily found in nature, however circular an economy may be, needs incentives for their production. Rival goods are ultimately finite in consumption. Rival goods are economic goods. Scarcity is a temporary local shortage of a good. The scarce good has to be produced. Without the right incentives, there is low probability of its spontaneous and efficient production. Government production is no guarantee of efficient production as government officials cannot know even what goods 
should be produced. And even if they could by some miracle have that information, the government has no inherent incentives to produce the good efficiently. So, we mostly count on a well-defined system of property rights to produce the needed incentives for dynamic efficiency. Private property rights are institutions that induce the development of intellectual and other property rights, saving, production, commerce and consumption. In a capitalist society, the pure public good has the substantive form of an idea, work of literature, music, art, etc. A form of intellectual property, recognized by the patent and copyright laws, firstly comes to life as an intermediary form of a club good. The necessary research and development costs are sunk in form of money, time, and effort as the real option of investment is exercised. Once successfully produced, its marginal cost of production is negligible, enabling the producer to earn monopoly profits. It may be argued that a government subsidy amounting to the cost of research and development may provide a more efficient solution, but then the question of who decides what goods are to be invented, researched and developed, stays largely unanswered. To achieve dynamic efficiency, one must sacrifice static efficiency. So, club goods are dynamically efficient but statically inefficient. To achieve both, one needs to have an optimal duration of copyrights and patents to provide for production incentives without excessive monopolistic profits for the producers. Various goods have different costs of research and development but not necessarily different patent expiration durations which leaves the market with many institutionally supplied monopolies. When the patent ultimately does expire, the good becomes a generic, public domain, pure public good.

The problem of the tragedy of the commons arises with common goods and common pool resources when the non-renewable and ultimately depletable (scarce) resource is depleted at a rate higher than its rate of renewal. The opportunity cost between present and future consumption of a nonrenewable common pool resource is the interest rate (the time preference rate). The rate of depletion of a common pool resource is equal to this rate. The difference between the rate of depletion and the rate of renewal can be seen as the goods' true marginal cost. In the case of common goods, the price is nil or under the marginal cost. To assure for dynamic efficiency, the good should be priced according to its marginal cost. Normally, this goes via privatisation. There are many nuances of property rights, and according to Ostrom et al. (1996), there is mostly no need to fully privatize a good to achieve desired efficiencies. Without some institutional mechanism of allocation, explicit or implicit pricing is impossible, and the depletion of common goods is almost guaranteed. The most effective allocation mechanism is the price. Price is simultaneously information and incentive (Hayek, 1945; Demsetz, 1964, 2011). A system of prices in a market economy fulfils several roles at once: allocation between consumption and production, and gives information on risks, marginal costs and marginal benefits. 
Table 9: Possibility and desirability of pricing

\begin{tabular}{|l|l|l|l|}
\cline { 3 - 4 } \multicolumn{2}{c|}{} & \multicolumn{2}{|l|}{ Opportunity costs of production (dynamic allocation) } \\
\cline { 2 - 4 } \multicolumn{2}{c|}{} & Positive & Non existent \\
\hline $\begin{array}{l}\text { Opportunity } \\
\text { costs in } \\
\text { consumption } \\
\text { (static allocation) }\end{array}$ & $\begin{array}{l}\text { Scarce } \\
\text { goods }\end{array}$ & $\begin{array}{l}\text { Pricing feasible and } \\
\text { desirable for dynamic and } \\
\text { static purposes. }\end{array}$ & $\begin{array}{l}\text { Pricing not feasible but } \\
\text { desirable. Through the } \\
\text { process of "propriation" } \\
\text { some aspects of it may be } \\
\text { privatized. }\end{array}$ \\
\cline { 2 - 4 } & $\begin{array}{l}\text { Non- } \\
\text { scarce } \\
\text { goods }\end{array}$ & $\begin{array}{l}\text { Pricing feasible and } \\
\text { desirable to repay for the } \\
\text { "sunk costs". In the long } \\
\text { run, the good becomes a } \\
\text { public good. }\end{array}$ & $\begin{array}{l}\text { Pricing neither feasible nor } \\
\text { desirable. Goods neither } \\
\text { locally nor temporarily } \\
\text { scarce, depletable nor } \\
\text { subtractable. }\end{array}$ \\
\hline
\end{tabular}

Source: Author's own representation.

\section{Conclusion}

There aren't enough resources around, regardless of production efforts. As long as there аге desires, and incentives to produce, the impact of scarcity on human lives is less dramatic. Scarcity is the main topic of economics. The goods are either scarce in production (there is a shortage thereof) or they are scarce in consumption (they are rival, depletable, subtractable).

To make the common goods dynamically more efficient we need an effective system of property rights that will cover this grey area. To make the club goods statically more efficient, we need to terminate their exclusive property rights just in time to still induce further investment, research, and development without causing static inefficiencies.

By examining their substantive characteristics, all goods fall into one of the four categories. The presented classification has several benefits: it avoids the accounting terms of fixed and variable costs that are prone to misclassification, it uses simple economic terminology, and it can easily be formally stated and graphically represented by using marginal rates of transformation in production possibility frontiers. The terms scarcity in production and scarcity in consumption fit perfectly the concept of analysis based on opportunity costs of production and opportunity costs in consumption. 
Davor Mance. University of Rijeka, Faculty of Economics Rijeka: teaching and research assistant on courses Anthropology, Philosophy of Economics. Scientific interest is focused on institutions and institutional mechanism design.

Nenad Vretenar, PhD. University of Rijeka, Faculty of Economics Rijeka: assistant professor on courses Organization and Philosophy of Rational Behavior. Scientific interest is mainly focused on the fields of organization and management, rational behavior and decision making.

Jana Katunar. University of Rijeka, Faculty of Economics Rijeka: teaching and research assistant on courses: Fundamentals of Entrepreneurship, The Economics of Entrepreneurship, Cost Management, Company valuation. 


\section{References}

Alchian, A. A., \& Demsetz, H. (1972). Production, information costs, and economic organization. American Economic Review, 62(Dec.), 777-795.

Bain, J. S. (1954). Economies of Scale, Concentration and the Condition of Entry in Twenty Manufacturing Industries. American Economic Review, 44(1), 15-39.

Baumol, W. J. (1964). External Economies and Second-Order Optimality Conditions. American Economic Review, 54(4), 358-372.

Baumol, W. J., \& Bradford, D. (1972). Detrimental Externalities and NonConvexity of the Production Set. Economica, New Series, 39(154), 160-176. DOI: $10.2307 / 2552639$

Baumol, W. J. (1982). Contestable Markets: An Uprising in the Theory of Industry Structure. American Economic Review, 72(1), 1-15.

Baumol, W. J., Panzar, J. C., \& Willig, R. D. (1982). Contestable Markets and the Theory of Industry Structure. New York: Harcourt Brace Jovanovich, Inc.

Buchanan, J. M. (1965). An Economic Theory of Clubs. Economica, New Series, 32(125), 1-14. DOI: $10.2307 / 2552442$

Buchanan, J. M. (2008). Opportunity cost. In S. N. Durlauf \& L. E. Blume (Eds.), The New Palgrave Dictionary of Economics (2nd ed.). Palgrave Macmillan. DOI: $10.1057 / 9780230226203.1222$

Cairncross, A. (1944). Introduction to Economics. London: Butterworth.

Coase, R. H. (1937). The Nature of the Firm. Economica, New Series, 4(16), 386405. DOI: $10.1111 / \mathrm{j} .1468-0335.1937 . t b 00002 . x$

Coase, R. H. (1946). The Marginal Cost Controversy. Economica, New Series, 13(51), 169-182. DOI: $10.2307 / 2549764$

Coase, R. H. (1960). The Problem of Social Cost. Journal of Law and Economics, 3(Oct.), 1-44. DOI: $10.1086 / 466560$

Coase, R. H. (1974). The Lighthouse in Economics. Journal of Law and Economics, 17(2), 357-376. DOI: $10.1086 / 466796$

Demsetz, H. (1964). The Exchange and Enforcement of Property Rights. Journal of Law and Economics, 7(Oct.), 11-26. DOI: 10.1086/466596

Demsetz, H. (1966). Some Aspects of Property Rights. Journal of Law and Economics, 9(Oct.), 61-70. DOI: 10.1086/466619

Demsetz, H. (1967). Toward a Theory of Property Rights. American Economic Review, 57(2), Papers and Proceedings of the Seventy-ninth Annual Meeting of the American Economic Association, 347-359.

Demsetz, H. (1968). Why Regulate Utilities? Journal of Law and Economics, 11(1), 55-65. DOI: $10.1086 / 466643$

Demsetz, H. (1973). Industry Structure, Market Rivalry, and Public Policy. Journal of Law and Economics, 16(1), 1-9. DOI: 10.1086/466752

Demsetz, H. (1982). Barriers to Entry. American Economic Review, 72(1), 47-57.

Demsetz, H. (2008). From Economic Man to Economic System. Cambridge, UK: Cambridge University Press. DOI: 10.1017/CBO9780511510656

Demsetz, H. (2011). The Problem of Social Cost: What Problem? A Critique of the Reasoning of A.C. Pigou and R.H. Coase. Review of Law and Economics, 7(1), 1-13. DOI: $10.2202 / 1555-5879.1502$

Hardin, G. (1968). The Tragedy of the Commons. Science, 162(3859), 1243-1248. DOI: $10.1126 /$ science.162.3859.1243 
Hayek, F. A. (1945). The Use of Knowledge in Society. American Economic Review, 35(4), 519-530.

Houthakker, H. (1956). Economics and Biology: Specialization and Speciation. Kyklos, 9(2), 181-189. DOI: 10.1111/j.1467-6435.1956.tb02717.x

Hurwicz, L. (1960). Optimality and Informational Efficiency in Resource Allocation Processes. In K. J. Arrow, S. Karlin \& P. Suppes (Eds.), Mathematical Methods in the Social Sciences. Stanford, CA: Stanford University Press.

Hurwicz, L. (1973). The design of mechanisms for resource allocations. American Economic Review, 63(2), 1-30.

Hurwicz, L., \& Reiter, S. (2006). Designing Economic Mechanisms. Cambridge, UK: Cambridge University Press. DOI: 10.1017/CBO9780511754258

Musgrave, R. A. (1939). Voluntary Exchange Theory of Public Economy. Quarterly Journal of Economics, 53(2), 213-237. DOI: 10.2307/1882886

Musgrave, R. A. (1959). The Theory of Public Finance. New York: McGraw-Hill.

North, D. (1990). Institutions, Institutional Change and Economic Performance. Cambridge, UK: Cambridge University Press.

DOI: $10.1017 / C B O 9780511808678$

Olson, M. (1965). The Logic of Collective Action: Public Goods and the Theory of Groups. Cambridge, MA: Harvard University Press.

Ostrom, E., \& Schlager, E. (1996). The Formation of Property Rights. In S. Hanna, C. Folke \& K.-G. Mäler (Eds.), Rights to Nature (pp. 127-156). Island Press.

Ostrom, E. (2003). How Types of Goods and Property Rights Jointly Affect Collective Action. Journal of Theoretical Politics, 15(3), 239-270. DOI: 10.1177/0951692803015003002

Ostrom, V., \& Ostrom, E. (1977). A Theory for Institutional Analysis of Common Pool Problems. In G. Hardin \& J. Baden (Eds.), Managing the Commons (pp. 157-172). San Francisco, CA: WH Freeman.

Robbins, L. (1932). An Essay on the Nature \& Significance of Economic Science. London: Macmillan and Co., Ltd.

Samuelson, P. A. (1954). The Pure Theory of Public Expenditure. Review of Economics and Statistics, 36(4), 387-389. DOI: 10.2307/1925895

Sen, A. (1977). Social Choice Theory: A Re-Examination. Econometrica, 45(1), 53-89. DOI: $10.2307 / 1913287$

Stigler, G. J. (1942). The Theory of Competitive Price. New York: Macmillan.

Stigler, G. J. (1951). The Division of Labor is Limited by the Extent of the Market. Journal of Political Economy, 59(3), 185-193. DOI: 10.1086/257075

Tirole, J. (2006). Theory of Corporate Finance. Princeton University Press.

Weitzman, M. (1983). Contestable Markets: An Uprising in the Theory of Industry Structure: Comment. Review of Economics and Statistics, 73(3), 486-487.

Wiśniewski, J. B. (2013). Non-Excludability, Externalities, and Entrepreneurship - An Overview of the Austrian Theory of Common Goods. Journal of Prices \& Markets, 1(1), 58-69. Available at SSRN: http://ssrn.com/abstract=2394889 
POVZETEK

1.02 Pregledni znanstveni članek

\section{Klasifikacija oportunitetnih stroškov, dobrin in trgov}

Ključne besede: klasifikacija dobrin in trgov, oportunitetni stroški, potencialni nepovratni stroški

$\checkmark$ luči nedavne Nobelove nagrade Jeanu Tiroleu so se avtorji članka odločili ponovno preučiti dve pomembni teoriji iz leta 1954 o klasifikaciji dobrin in trgov (ki sta osnova vsem univerzitetnim ekonomskim študijam) in tudi o vladnem zagotavljanju javnih dobrin, o vladnih protimonopolnih politikah in o politikah tržne koncentracije.

Teoriji sta Samuelsonova teorija (1954) o klasifikaciji dobrin v dobrine zasebne in skupne potrošnje ter Bainova teorija (1954) o endogenih tržnih strukturah. Obe teoriji se poučujeta ločeno tako v makroekonomiji, kot tudi v mikroekonomiji, čeprav imata enako teoretično ozadje, ki se ga pogosto zanemarja.

Dobrine se klasificirajo po merilih tekmovalnosti in izključenost iz potrošnje, tržne strukture pa po subaditivnosti in ireverzibilnosti v proizvodnji, to je po oportunitetnih stroških proizvodnje in oportunitetnih stroški v potrošnji. Oportunitetni stroški proizvodnje v obliki potencialnih nepovratnih stroškov spodbujajo investicije in proizvodnjo. Potencialni nepovratni stroški imajo vlogo neizkoriščene realne možnosti za investicije. Če se ta možnost izkoristi, postanejo potencialni nepovratni stroški nepovratni, sprožijo uvajanje subaditivnosti, specializacijo in konveksnost mejne stopnje tehnične substitucije. To je osnova Baumolove (1982) sporne tržne teorije, ki temelji na Bainovi (1954) teoriji endogenih tržnih struktur in kasnejše harvardske paradigme struktura-ravnanje-učinkovitost (SCP).

Paradigma SCP je osnova sodobne teorije o industrijski organizaciji in vladnih protimonopolnih politikah ter politikah tržne koncentracije. Z uporabo Demsetzovih (1968) argumentov se oportunitetni stroški v potrošnji določajo z mejnimi stroški substitucije in se končajo z argumentom, da so za njihovo dobavo, namesto vladne proizvodnje, potrebne institucije in mehanizmi za spodbujanje proizvodnje. Pred šestdesetimi leti se je razprava končala brez odkritja vseobsegajoče klasifikacije dobrin, ki bi upravičila vladno zagotavljanje javnih dobrin, medtem ko sedanje protimonopolne politike in politike o koncentraciji še vedno niso usklajene.

1 Predstavljeno delo je podprla Univerza v Reki v okviru projektov številka 13.02.1.3.11 in 13.02.1.2.09. 
Klasifikacija Samuelson-Musgrave-Buchanan-Ostrom ne razloži niti ne upravičuje vladne vloge pri zagotavljanju dobrin. Vlada večinoma zagotavlja zasebno potrošnjo dobrin, saj so dobrine, ki jih dobavlja, bodisi pokvarljive oziroma minljive ali konkurenčne $v$ potrošnji. Skupno potrošnjo dobrin večinoma zagotavlja zasebni trg, saj so bolj učinkovito proizvedene v sistemu, ki temelji na konkurenčnem trgu z močnimi spodbudami za proizvodnjo - v okolju subaditivnosti stroškov in superaditivnosti dobička. Na področju tržnih struktur, empirična raziskava ne ustreza teoriji in tržna koncentracija ne omogoča sklepanja o konkurenčnosti. Članek v devetih razpredelnicah predlaga novo klasifikacijo, ki močno črpa iz omenjenih teorij, jih pojasnjuje in dopušča uvedbo institucionalne/ekonomske dihotomije. Predstavljena klasifikacija ima več prednosti: izogiba se računovodskim izrazom o fiksnih in variabilnih stroških, ki se jih pogosto napačno razvršča, uporablja enostavno ekonomsko terminologijo, mogoče jo je enostavno formalno navajati in z mejnimi ravnmi transformacije $v$ proizvodnji možnih meja tudi grafično predstavljati. 